\title{
INFLUENCE OF VANES SHAPE ON THE HIGH FREQUENCY NOISE OF VENTILATED DISC BRAKES IN HEAVY VEHICLES
}

\author{
Nadica Stojanovićl, Jasna Glišović, Jovanka Lukić, Ivan Grujić
}

UDC: $621.01: 62.592+534.322 .3$

DOI: $10.24874 / m v m .2017 .43 .03 .01$

\begin{abstract}
Brake is a device for slowing or stopping the vehicle. The sound that occurs in the process of braking is very irritating for the driver. Brake systems of road vehicles as important factor in overall vehicle noise have attracted great attention. All global brake system manufactures are focused to the quieter brakes. This paper presents an analysis of differentially variants of brake disc, and how the structure itself influencing the occurrence of noise. The weight of analyzed discs is approximately equal to each other. The analysis was performed in the software package ANSYS, while the model was created in CATIA.
\end{abstract}

KEY WORDS: noise, brakes, manufactures, structure, modal analysis

\section{UTICAJ OBLIKA REBARA NA VISOKOFREKVETNU BUKU VENTILIRAJUĆIH DISK KOČNICA TERETNIH VOZILA}

REZIME: Kočnica je uređaj za usporavanje ili zaustavljanje vozila. Zvuk koji se javlja u procesu kočenja je jako iritirajući za vozača. Veliku pažnju kod drumskih vozila upravo su privukli kočni sistemi kao važni faktor u ukupnoj buci vozila. Svi svetski proizvođači kočnica su se usmerili ka tišim kočnicama. U radu je prikazana analiza za različitie varijante disk kočnica, odnosno kako sama konstrukcija utiče na pojavu buke. Analizirane varijante diskova su približno istih masa. Analiza je izvršena u softverskom paketu ANSYS, dok je model izrađen u CATIA.

KLJUČNE REČI: buka, kočnice, proizvođači, konstrukcija, modalna analiza.

${ }^{1}$ Received: June 2017, Accepted August 2017, Available on line December 2017 
Intentionally blank

Volume 43, Number 3, 2017 


\title{
INFLUENCE OF VANES SHAPE ON THE HIGH FREQUENCY NOISE OF VENTILATED DISC BRAKES IN HEAVY VEHICLES
}

\author{
Nadica Stojanović ${ }^{1}$, Jasna Glišović ${ }^{2}$, Jovanka Lukić ${ }^{3}$, Ivan Grujić ${ }^{4}$
}

\section{INTRODUCTION}

Brake is a device for slowing or stopping the rotation of a wheel while maintaining stability of vehicle. The auxiliary brakes have important task to keep the vehicle stationary. There are two basic design solutions of friction brakes as the executive mechanisms of road vehicles braking systems: the disc and drum brakes. However, today the largest application in both passenger and commercial vehicles, have the disc brakes. Paper title points out that the paper will be focused on the disc brakes of heavy-duty commercial vehicles. Braking in this case is accomplished by the friction that occurs in the contact of disc and the pads.

One of the main characteristics of a modern urban society is the growing presence of sounds that cause discomfort. A large number of sounds one experiences subjectively. The sound can be pleasant and unpleasant. Pleasant sounds are those like the twitter of birds, or favourite songs, while the unpleasant sounds are very irritating. Unpleasant sounds can be like music that an individual does not like or sounds typical for the industrial areas. These sounds are called noise [1]. Noise is one of the stimulus from the environment which acts on the man and affecting his health, working ability and comfort [2].

Brake noise and judder of road vehicles are of great importance both for manufacturers and for the customers [3]. The noise level in any area is in direct correlation with the quality of life there, as well as the environment pollution [4]. Also, the noise level of the brake system is directly reflected on road safety. Noise level directly affects alertness of drivers. A large number of research and experience have raised the level of understanding of the occurrence of brake noise. By applying the experience of others, still in the design phase, susceptibility to noise and vibration is significantly reduced.

In the process of finding solutions to reduce the noise of the brake system, Nouby and Srinivasan [5] have carried out a few analyses. Analyses included some of the factors that contribute to the noise generation. The conclusions reached by the authors of this paper are:

- The higher coefficient of friction increases the possibility of noise,

- The brake noise can be reduced by decreasing the stiffness of the back plates of the pads, and

1 Nadica Stojanović, M.Sc., assist., University of Kragujevac, Faculty of engineering, Sestre Janjić 6, 34000 Kragujevac, Serbia, nadica.stojanovic@kg.ac.rs

${ }^{2}$ Jasna Glišović, Ph.D., assoc. prof., University of Kragujevac, Faculty of Engineering, Sestre Janjić 6, 34000 Kragujevac, Serbia, jaca@kg.ac.rs

${ }^{3}$ Jovanka Lukić, Ph.D., prof., University of Kragujevac, Faculty of engineering, Sestre Janjić 6, 34000

Kragujevac,Serbia,lukicj@kg.ac.rs

${ }^{4}$ Ivan Grujić, M.Sc., assist., University of Kragujevac, Faculty of engineering, Sestre Janjić 6, 34000 Kragujevac,Serbia, ivan.grujic@kg.ac.rs 
- Increasing the size of the chamfer provided significant noise reduction.

Reduction of brake noise is possible to achieve by the design modifications of a disc [6]. Several structural changes were made to the disc, and the analysis was performed for each change using CAE. The modifications that were made to disc: the change in the number of blades, the thickness of the neck, as well as height, holes on the disc etc. Despite numerous modifications made to the disc and any change was tested, it was shown that noise cannot be eliminated. The noise that occurs in the brake system depends not only on the design of the disc.

Mat Lazim and others [7] showed that the wear of brake pads surface affect the squeal of brakes. Also, this paper shows that it is not the same level of noise if it is a new brake pad or brake pad that is already in operation. Based on the research results, it was concluded that for the development of quieter brake system, it is essential to understand the topography of brake pad surface.

The aim of this paper is to examine how the shape of the brake disc ribs affects the brake noise, which occurs in the process of braking.

\section{CAD MODEL OF BRAKE DISC}

A compressed air disc brake system is a type of friction brake for vehicles in which compressed air pressing on a piston is used to apply the pressure to the brake pad needed to stop the vehicle. Air brakes are used in large heavy vehicles, particularly those having multiple trailers which must be linked into the brake system, such as trucks, buses, trailers, and semi-trailers. Air disc brake (ADB) is the execution unit of automobile brake, which plays a vital role in traffic safety. The first air brakes were primarily developed for use in railway vehicles. The main reason for the application was to improve their braking responsiveness and safety and avoid the all too frequent train crashes. Westinghouse made numerous alterations to improve his air pressured brake invention, which led to various forms of the automatic brake. In the early 20th century, after its advantages were proven in railway use, it was adopted by manufacturers of trucks and heavy road vehicles [8]. Air disc brake assembly modelled in CATIA software package is shown in Figure 1.

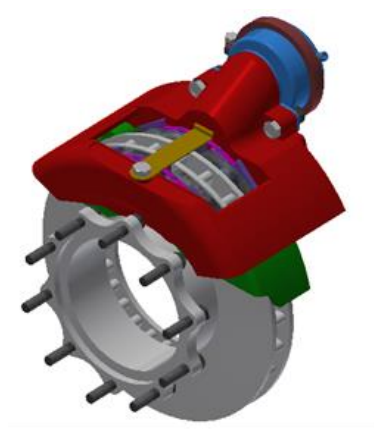

Figure 1. Air disc brake in heavy duty commercial vehicles

The braking system assembly consists of a large number of parts (Figure 1). However, in the analysis that is performed in the paper, only brake disc and pads are observed. Friction pair consists of disc and brake pads is modelled in the software package CATIA and as such will be imported into the software for further analysis. The design of the 
heavy vehicles

disc varies somewhat. Some are simply solid, but others are hollowed out with ribs or vanes joining together the disc's two contact surfaces. The weight and power of the vehicle determines the need for ventilated discs. The ventilated disc design helps to dissipate the generated heat under extreme braking conditions and is commonly used on the moreheavily-loaded front discs. The outer diameter of the analysed disc is $430 \mathrm{~mm}$ [9]. The analysis is performed for the completely new disc, whose height is $131 \mathrm{~mm}$ and thickness is $45 \mathrm{~mm}$. Four variants of the ribs of the brake disc are shown in Figure 2.

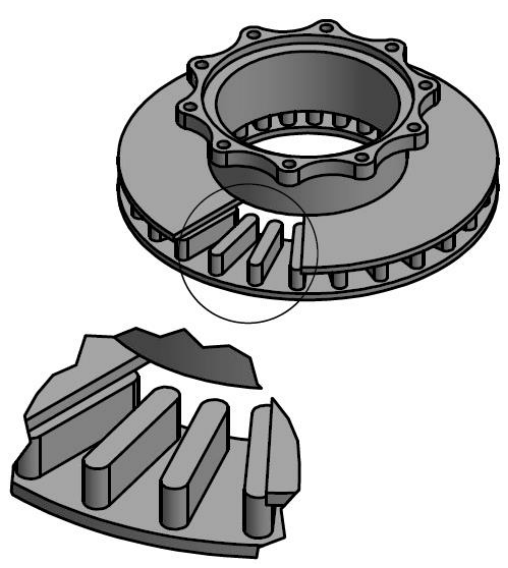

a) $M 1$

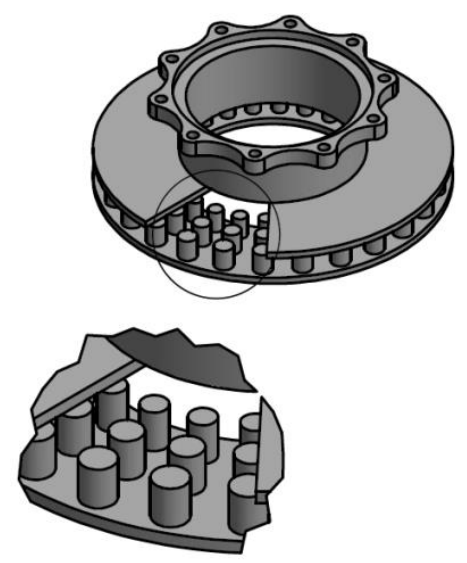

c) $\quad M 3$

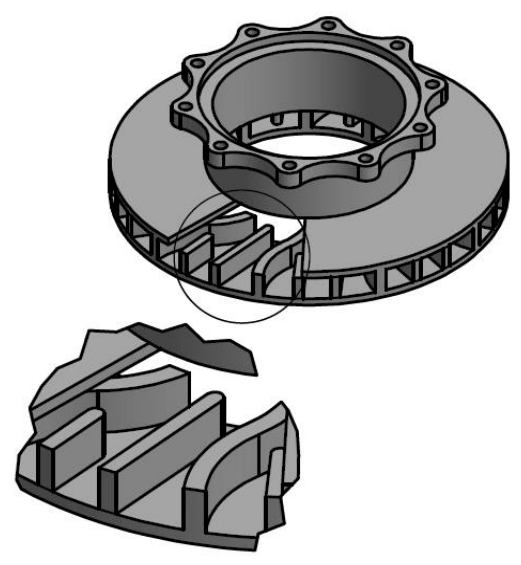

b) $\quad M 2$
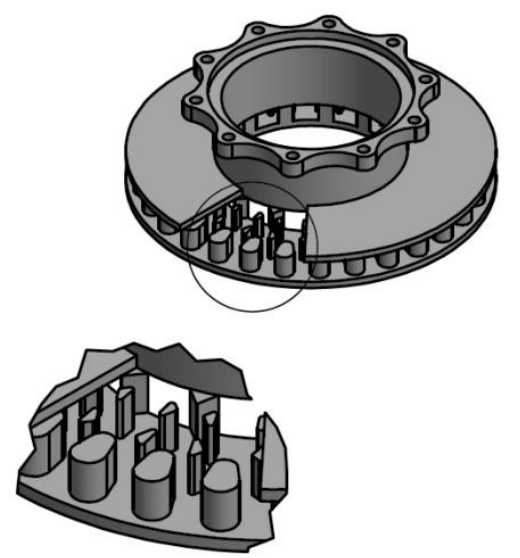

d) $M 4$

Figure 2. Ventilated brake disc with various variants of the ribs

In most vehicles these brake discs are made of cast iron, which has good antiwear properties and it is cheap as well. The material used for the disc is cast iron, while the friction material is used for the brake pads. Material properties are shown in Table 1, while Table 2 shows the mass variations of each disc. It is obvious that the mass of the discs is approximately equal. 
Table 1. Material properties of the brake disc and brake pads [10]

\begin{tabular}{|c|c|c|c|}
\hline & Density $\left(\mathrm{kgm}^{-3}\right)$ & Young's modulus $(\mathrm{GPa})$ & Poison ratio (-) \\
\hline Disc & 7250 & 138 & 0.28 \\
\hline Pads & 1400 & 1 & 0.25 \\
\hline
\end{tabular}

Table 2. Mass of discs with different variants of the ribs

\begin{tabular}{|c|c|c|c|c|}
\hline & M1 & M2 & M3 & M4 \\
\hline Weight $[\mathrm{kg}]$ & 24.332 & 24.267 & 24.359 & 24.226 \\
\hline
\end{tabular}

\subsection{Boundary conditions}

Boundary conditions are applied according to the loading for the real component of the structure. First, it is necessary to define the initial conditions. Initial conditions are defined in the module Static Structural. An environmental condition, in which the vehicle is tested, defines with the ambient temperature of $22^{\circ} \mathrm{C}$.

Brake squeal is predominantly generated at low vehicle speeds (below $30 \mathrm{~km} / \mathrm{h}$ ) and at low brake pressures (brake line pressure below $2 \mathrm{MPa}$ ). From many experimental observations, it is known that squeal usually occurs at slow rotational speeds (around 0.1-1 $\mathrm{Hz}$ or $6-60 \mathrm{rev} / \mathrm{min}$ ) towards the end of a stop. The vehicle is moving with a speed of 20 $\mathrm{km} / \mathrm{h}$ and braking until it completely stops. Based on the initial speed of the vehicle and the tire diameter, calculated angular speed is $10 \mathrm{rad} / \mathrm{s}$.

Brake squeal noise is the result of vibration created by coupling of two vibration modes of brake component such as pads, rotor, calliper, suspension links etc. In mode coupling mechanism, two modes of vibration geometrically matched (same wavelength) and close resonances can induce more energy into the system than it can dissipate. The mode coupling is often locked depending on operational conditions such as (speed, pressure and temperature) and interface characteristics such as contact stiffness, roughness, adhesive force, etc. Actually, the disc speed is an indirect simulation parameter in the sense that it affects the friction coefficient which plays a major role in the analysis.

Friction in most mechanical element is undesirable phenomenon. However, in the brake system it is very desirable. Without friction vehicle could not be stopped. Brake friction pair, namely the friction material and the rotor, is the area where the friction is realized over a wide range of operational and environmental conditions. The value of the coefficient of friction is 0.336 [11].

\subsection{Modal analysis}

Modal analysis has become one of the most important tools in the design and structural optimization of mechanical product. It has been used effectively in the identification of structural dynamic characteristics and has become a flourishing area of vibration research [12]. Modern constructions should be as lightweight and simple, but at the same time strong enough [13]. These requirements are the most prominent in the automotive industry. However, if you do not pay attention, it can lead to undesirable vibrations in certain vehicle operating modes. 
heavy vehicles

Modal analysis is the process of determining the basic dynamic properties of the structure, such as natural frequency, damping and oscillation modes, in order to formulate the dynamic behaviour of the model. The analysis is based on the fact that the vibrations of the nonlinear dynamic system can be represented by the sum of simple harmonic motions. Fourier theory is based on this fact, where all the complex oscillation modes can be represented by a sum of sine and cosine oscillation modes, with the appropriate frequency, amplitude and phase constants [14]. Oscillation modes of the disc M1 is shown in Figure 3.

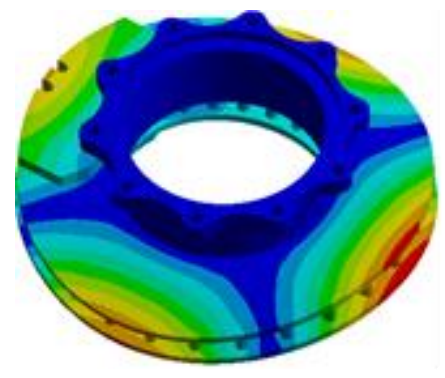

a) Mode shape 2 at a frequency of $997.498 \mathrm{~Hz}$

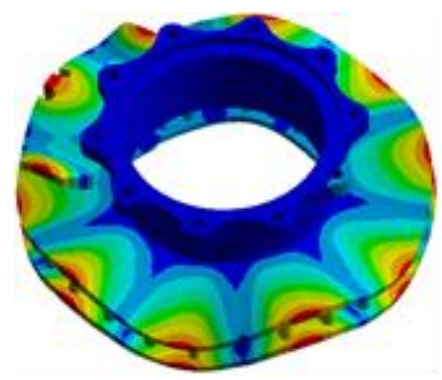

d) Mode shape 5 at a frequency of $3642.22 \mathrm{~Hz}$

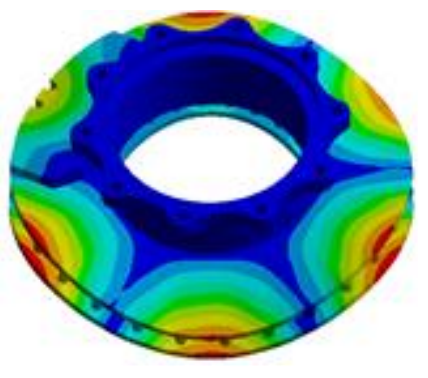

b) Mode shape 3 at a frequency of $1876.78 \mathrm{~Hz}$

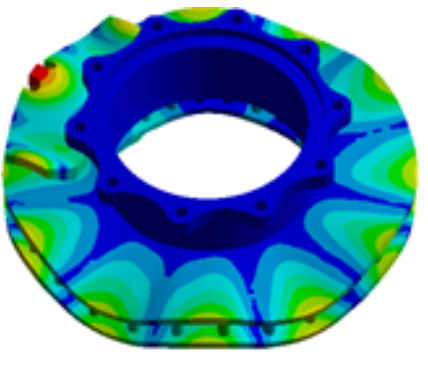

e) Mode shape 6 at a frequency of $4415.79 \mathrm{~Hz}$

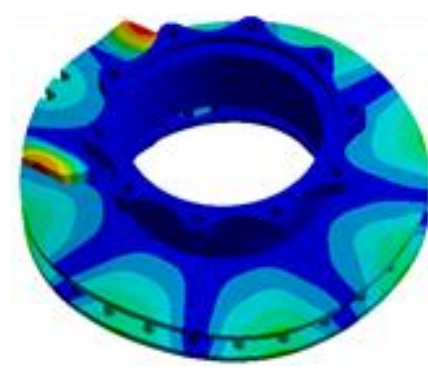

c) Mode shape 4 at a frequency of $2804.1 \mathrm{~Hz}$

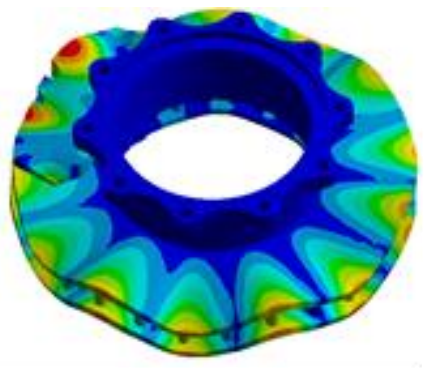

f) Mode shape 7 at a frequency of $5157.74 \mathrm{~Hz}$

Figure 3. Disc modes shapes during braking

\subsection{Analysis of the results for different models of ventilated discs}

The results obtained from the analysis performed in the software package ANSYS, using module Static Structural and Modal, are shown in Table 3. To get a better idea of the value of frequencies in each mode, the chart is shown in Figure 4.

Table 3. Comparative values of the disc modes frequencies

\begin{tabular}{|c|c|c|c|c|c|c|}
\cline { 2 - 7 } \multicolumn{1}{c|}{} & 2 & 3 & 4 & 5 & 6 & 7 \\
\hline M1 [Hz] & 997.498 & 1876.78 & 2804.1 & 3642.22 & 4415.79 & 5157.74 \\
\hline M2 [Hz] & 1002.9 & 1885.9 & 2865.3 & 3734.8 & 4445.33 & 5145.4 \\
\hline M3 [Hz] & 1211.3 & 2078.43 & 3021.14 & 4098.76 & 4969.76 & 5684.95 \\
\hline M4 [Hz] & 1014.02 & 1984.74 & 2931.59 & 3715.78 & 4582.22 & 5303.68 \\
\hline
\end{tabular}




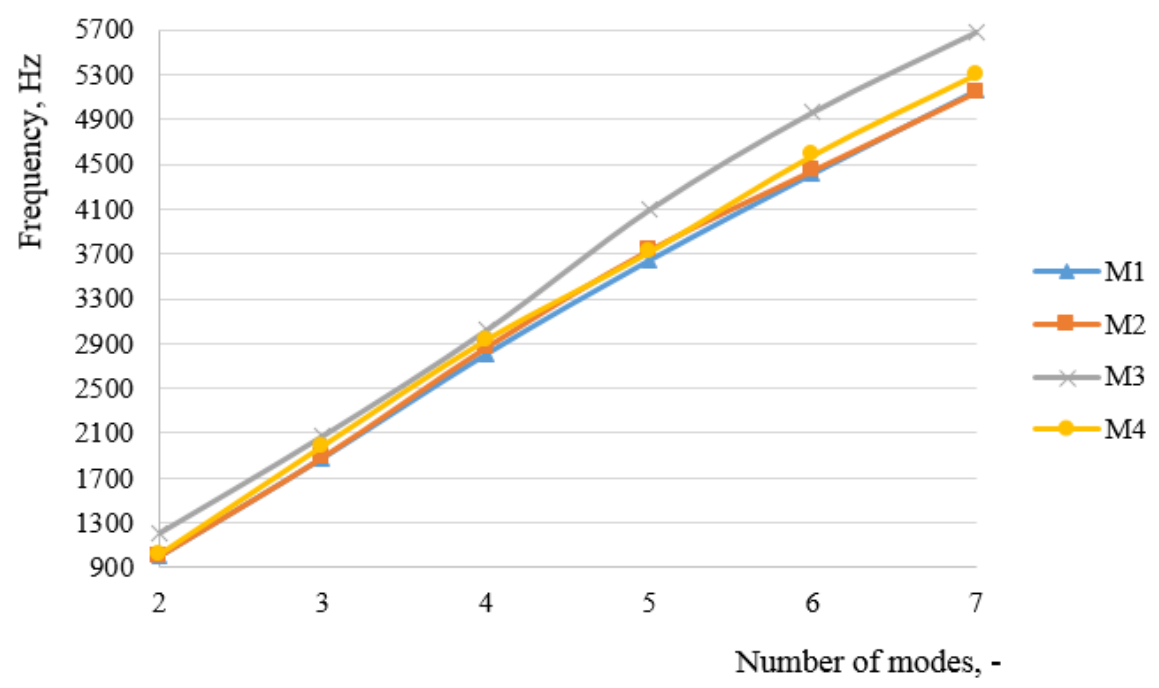

Figure 4. Chart illustration of modes for different variants of disc

Analysis of obtained results from Figure 4 shows that at the variant of ventilated disc labeled M3 instabilities occur in higher frequency than in others, while other variants have approximately the same frequencies. The trend line, which indicates a change of the frequency depending on the number of modes, is nearly linear for each model of disc. However, disc with radial ribs labeled M1 have the lowest frequency for every number of modes.

\section{CONCLUSION}

It is very important that in daily use of vehicle i.e. in the process of braking, noise is reduced to minimum. Noise is one of the factors that affect driver fatigue, which often results in a traffic accident. Vigilance of the driver is very important because in some accident situations he should react on time and in the right way.

Most of the researchers have agreed that squeal noise in the disc brake is initiated by instability due to friction forces, contributing to self-excited vibrations. Modal analysis of brake disc has been carried out for the materials grey cast iron as it is one of the essential parts of the brake system which contributes more in the generation of noise. First seven modes are extracted for the disc for predicting the natural frequencies. The mode coupling is often locked depending on operational conditions and characteristics such as contact stiffness, roughness, adhesive force, etc. Finite element model of the ventilated brake disc rotor was developed to study the influence of various variants of the ribs on the modalities of the brake rotor disc. Conducted analysis has shown that the variant of ribs labelled as M3 has a greater extent, while other variants have a negligible impact on the frequency of analysed modes. It is necessary that in future research to include other elements of the brake assembly in analysis. Of course, in addition, it is necessary to verify results obtained by numerical methods by the experimental research. 
Influence of vanes shape on the high frequency noise of ventilated disc brakes in heavy vehicles

\section{ACKNOWLEDGMENT}

This paper was realized within the researching project "The research of vehicle safety as part of a cybernetic system: Driver-Vehicle-Environment" ref. no. TR35041, funded by Ministry of Education, Science and Technological Development of the Republic of Serbia.

\section{REFERENCES}

[1] Budimčić M., Assessment of the facts of loud music on hearing loss in young adults, $\mathrm{PhD}$ Thesis, Faculty of Medical Sciences, Kragujevac, 2015.

[2] Lukić J., Complex Vehicle Comfort, Faculty of Mechanical Engineering, Kragujevac, 2011.

[3] Day A., Braking of Road Vehicle, Waltham, 2014, ISBN 978-0-12-397314-6.

[4] Gruden D., Introduction, The Handbook of Environmental Chemistry, Springer, Vol. 3, Part T, Berlin, 2003, pp 1-13.

[5] Nouby M., Srinivasan K., Disc Brake Squeal Reduction Through Pad Structural Modifications, International Conference on Recent and Emerging Advanced Technologies in Engineering, Kuala Lumpur, Malaysia, 2009.

[6] Nouby M., Sujatha C., Srinivasan K., Modelling of automotive disc brake squeal and its reduction using rotor design modifications, International Journal of Vehicle Noise and Vibration, Vol. 7, No. 2, 2011.

[7] Mat Lazim A. R., Abdul Hamid M. K., Abu Bakar A. R., Effects of Pad Surface Topography on Disc Brake Squeal, Applied Mechanics and Materials Vol. 165, 2012, pp 58-62.

[8] European Braking Systems, Internet address: https://www.europeanbrakingsystems. co.uk/history, accessed 18.12.2016.

[9] UAB ECOBALTIC, Internet address: http://www.ecobaltic.lt/files/stabdziu_dalys/ nca104720.pdf, accessed 18.12.2016.

[10] Belhocine A., Numerical investigation of a three-dimensional disc-pad model with and without thermal effects, Thermal science, vol. 19, no. 6, pp 2195-2204, 2012.

[11] Glišović, J., Theoretical and experimental research of high-frequency noise of disc brakes, PhD Thesis, University of Kragujevac, Faculty of Engineering, Kragujevac, 2012.

[12] Jimin H., Zhi-Fang F., Modal Analysis, Butterworth-Heinemann, Great Britain, ISBN $0750650796,2001$.

[13] Veg E., Integrity assessment by cross correlated modal identification of steel structures, PhD Thesis, Faculty of Mechanical Engineering, Beograd, 2015.

[14] Kun-Shan L., Gene F., Ray S., The TMS320 Family of Digital Signal Processors, Texas, 1997. 